Brit. F. industr. Med., 1966, 23, 204

\title{
Prognostic Aspects of Benzene Poisoning
}

\author{
S. HERNBERG, M. SAVILAHTI, K. AHLMAN, and S. ASP \\ From the Institute of Occupational Health, Helsinki, and the Central Hospital of Hämeenlinna, \\ Finland
}

In 1955, a benzene mass-poisoning was detected in a shoe factory in Finland. One hundred and fortyseven persons were heavily exposed, and more than roo had abnormal blood counts. One died and Io required hospital treatment. This paper deals with a re-examination of the involved workers nine years later. One hundred and twenty-five persons attended for re-examination. Eight had died, two refused, and I I could not be located. The possibility of death due to benzene poisoning having occurred among these persons was ruled out by checking the national death register. Each of the subjects underwent a haematological examination which included the haemoglobin value and the erythrocyte, reticulocyte, leucocyte, and thrombocyte counts. A differential count of the leucocytes was also made. A randomly chosen group of 86 persons served as a control group. The thrombocytes of the whole patient group and the erythrocytes of the men were significantly lower than those of the controls, whereas the leucocytes of the whole group and the erythrocytes of the women failed to show any statistical difference. In a multiple discriminant function analysis, considering all three counts at the same time, only the men differed slightly from the controls at the re-examination. The analysis also showed that the prognosis of the severe cases did not differ from that of the mild ones, provided the acute stage had been passed. Some illustrative case reports are added. One patient developed leukaemia after a latency of seven years, whereas most of the others-chosen because of grave symptoms in the initial stage-have recovered. The results are discussed from the point of view of prognosis.

The haematological manifestations of chronic benzene poisoning are characterized by anaemia, leucopenia, and thrombocytopenia, either alone or in combination. The course of the poisoning varies. Even if most patients probably recover, provided the exposure is terminated, it is well known that fatal aplasia of the bone marrow may develop. Benzene-induced leukaemia, first reported in 1928 by Delore and Borgomano, is another serious complication (Zeyer, 196I; Wintrobe, 196I ; Vigliani and Saita, 1964). The literature is, however, rather poor in longitudinal studies regarding the fate of whole patient groups. In 194I Goldwater and Tewksbury published a study of 108 men in whom distinct abnormalities in the blood picture persisted in four, and mild changes occurred in eight, 24 months after the exposure had ceased. Helmer (1944) observed 60 patients for 16 months. At the end of this period two were dead and I2 still had abnormal blood counts. Rejsek and Rejsková (1955) found ro severe cases of poisoning among 4,500 workers exposed to benzene. Twelve years later one had died, another had fully recovered, and the remainder still showed

Received for publication November 3, 1965. different types of leucopenia. Saita (1955) followed 18 patients for two years. Only one recovered completely, and the blood picture of the others remained pathological. Kauppila and Setälä (1956) published five cases and recorded two deaths. The survivors were observed for 18 months, three, and three years respectively. At the end of the follow-up, none of the patients had fully recovered. Coscia, Perrelli, and Meo (1963) have recently published a study in which haematological abnormalities persisted for one to three years in some cases in spite of withdrawal of the patients from exposure. All these studies, even if they throw some light on the prognostic aspects, deal with either a small number of cases or a short observation time. We are not aware of any studies in which large groups of patients have been re-examined several years after the cessation of exposure.

In 1956, Savilahti published a paper dealing with benzene intoxication among 147 workers in a shoe factory. Benzene had been used in the factory since I941. An air sample analysis at the end of 1954 revealed very high concentrations of benzene (318433-470 p.p.m., the maximal allowable concentration being 25 p.p.m.). At the time of the examina- 
tion (summer 1955) 107 persons had abnormal blood pictures. One patient died and Io required hospital treatment. The workers were followed for one year, and after that time 2 I still had blood counts that were abnormal in some respect. The present study deals with a re-examination of these workers nine years after the first examination. None of them has since been in contact with benzene, which was withdrawn immediately after the accident.

\section{Materials and Methods}

Out of the original 147 persons, 125 (39 men and 86 women) attended the re-examination. It was impossible to trace II persons (Table I). In order to exclude the possibility of benzene-induced deaths among them,

TABLE I

DISTRIBUTION OF THE ORIGINAL I47 CASES IN 1964

\begin{tabular}{lccr} 
& Male & Female & Total \\
\hline Subjects examined & 39 & 86 & 125 \\
Death due to benzene & I & $-\star$ & I \\
Death from other causes & 7 & I & 8 \\
Subjects refusing examination & I & I & 2 \\
Unknown & 2 & 9 & I I \\
Total & 50 & 97 & 147 \\
$\quad$ One patient died later of leukaemia (see case $\mathrm{I}$ ).
\end{tabular}

e.g., aplastic anaemia or leukaemia, we checked the national death register. As none of the missing persons was found in it, we concluded that they were still alive.

The two patients who refused examination stated that they were quite well at the time. The deaths from causes other than benzene are shown in Table II.

\section{TABLE II}

Cause

No.

Parathione (suicide)

Cardiac decompensation or infarction

Carcinoma of the stomach

Total

2

Seventy-two persons were still employed in the same shoe factory (but not exposed to benzene), and 55 had moved to other occupations or had retired. The occupational data of I I persons were not available.

A group of 39 men and 47 women of the same socioeconomic status served as controls. The blood counts were obtained at a group health examination, and no one taking part in it was rejected because of illness or other causes. The control group is therefore not 'normal' material but a representative sample of the same social category as the exposed group. The haematological examination included the following laboratory procedures: sedimentation rate, haemoglobin value, and erythrocyte, reticulocyte, leucocyte, and thrombocyte counts. A differential count of the leucocytes was also made. The examinations were made using standard techniques. About $85 \%$ of the blood counts of the exposed group, and all those of the control group, were performed in the same laboratory (County Hospital of Hämeenlinna) and the remainder in other laboratories in different parts of Finland.

The haemoglobin value is influenced by iron deficiency more than is the erythrocyte count. The high incidence of iron deficiency among the Finnish population (Antila, I962) therefore makes the haemoglobin value less suitable for this study. The reticulocyte count and the differential count of the leucocytes did not reveal anything of interest. Therefore only the erythrocyte, leucocyte, and thrombocyte counts are used for statistical purposes.

Statistical Analysis Examination of the frequency distribution of the three variables under analysis indicated that they were normally distributed in both the exposed and the control groups. This made it possible to use the mean values as parameters in comparative studies. The reliability of the mean difference for each of the variables was examined using the $t$ test. The group differences were further analysed using a multiple discriminant analysis (Fisher, 1938). With this approach, an appropriate test of the statistical significance of the separation of groups on a particular discriminant function can be made.

\section{Results}

Pathological blood values must be expected to occur in every randomly chosen group, provided it is large enough. Therefore, the evaluation of the findings is made only by comparing the exposed group with the control group. Table III shows the mean values and standard deviations of the erythrocyte, leucocyte, and thrombocyte counts of the exposed group in 1955 and 1964, as well as the corresponding variables of the control group. The statistical significances of the differences of the means are shown in Table IV.

According to these results, the leucocyte count, though distinctly low in 1955, has attained values which do not differ statistically from those of the control group. The same is true for the erythrocytes of the females, whereas those of the males still show a difference. The thrombocytes of the whole group are still significantly lower in the exposed group.

Because a study of single counts will give an insufficient description, the whole situation could be better described by combining erythrocyte, leucocyte and thrombocyte counts together, using a multiple discriminant function analysis. The results of such a statistical treatment (Fisher, 1938) are given in Table $\mathrm{V}$. 
TABLE III

Mean Values and Standard Deviations of the Erythrocytes, Leucocytes, and Thrombocytes OF THE EXPOSED GROUP AND THE CONTROLS

\begin{tabular}{|c|c|c|c|c|c|c|}
\hline & \multicolumn{4}{|c|}{ Exposed Group } & \multirow{2}{*}{\multicolumn{2}{|c|}{ Control Group }} \\
\hline & \multicolumn{2}{|l|}{1955} & \multicolumn{2}{|l|}{1964} & & \\
\hline & Mean & S.D. & Mean & S.D. & Mean & S.D. \\
\hline \multicolumn{7}{|c|}{ Erythrocytes (mill.) } \\
\hline In males & $4 \cdot 42$ & 0.43 & 4.40 & $0.4 I$ & $4 \cdot 70$ & 0.36 \\
\hline In females & 3.90 & 0.52 & $4 \cdot 17$ & 0.32 & $4 \cdot 14$ & 0.30 \\
\hline $\begin{array}{l}\text { Leucocytes } \\
\text { Thrombocytes }\end{array}$ & $\begin{array}{r}4,738 \\
176,480\end{array}$ & $\begin{array}{r}1,549 \\
67,600\end{array}$ & $\begin{array}{r}5,932 \\
257,360\end{array}$ & $\begin{array}{r}1,243 \\
65,600\end{array}$ & $\begin{array}{r}6,366 \\
293,020\end{array}$ & $\begin{array}{r}2,154 \\
63,400\end{array}$ \\
\hline
\end{tabular}

TABLE IV

Statistical Significance of the Difference Between the Means of the Single Blood Counts OF THE EXPOSED GROUP AND THE CONTROLS

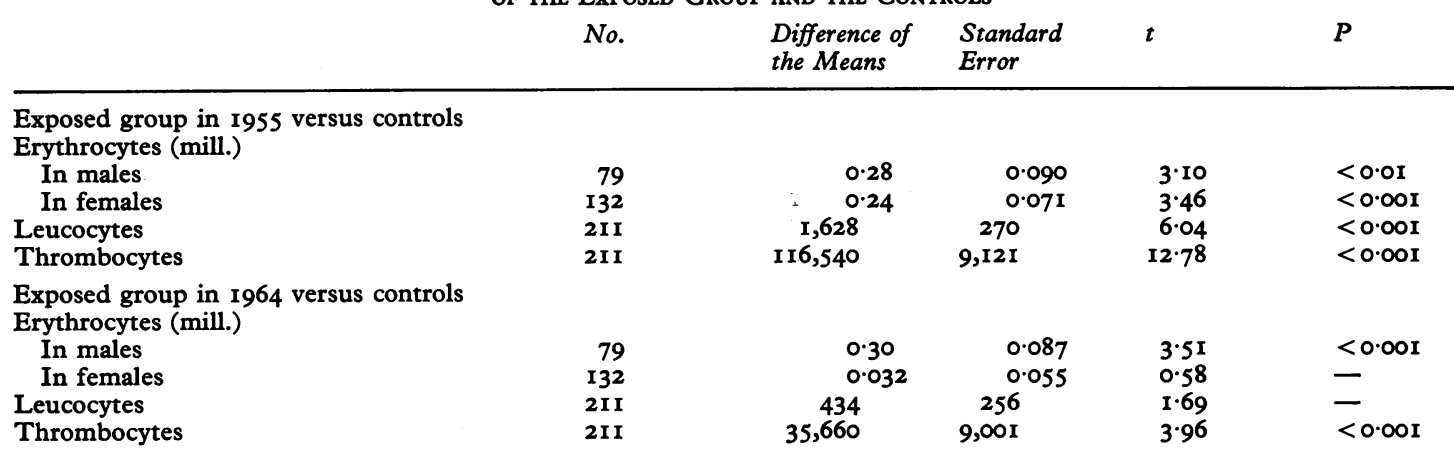

The difference between the exposed group and the controls in 1955 was highly significant, but in I964 the situation had changed-only the men showed a slight difference $(\mathbf{P}<0.05)$. According to this method, the group differences in 1964 were not marked, thereby indicating that the rate of recovery was high.

The affected group, however, is not homogeneous. It comprises both very severe and quite symptomless cases, as well as all the intermediate grades. We therefore decided to investigate whether the severe cases differed from the mild ones at the time of the re-examination.

TABLE V

Group Differences BetweEn Exposed aND Control Groups: Results of MUltiple Discriminant ANalysis

\begin{tabular}{lll} 
& $F$ & $P$ \\
\hline $\begin{array}{lll}\text { Exposed group in I955 versus controls } \\
\text { Males }\end{array}$ & 26.27 & $<0.001$ \\
Females & 30.38 & $<0.001$ \\
Exposed group in 1964 versus controls & & \\
$\quad$ Males & 3.14 & $<0.05$ \\
Females & 1.66 & -
\end{tabular}

The classification of the exposed group in 1955 into 'severe' and 'mild' intoxication was made in the following way. The three counts in question were numbered serially, the lowest number representing the most pathological value. The serial numbers were added, thereby giving an index of each person. Using these figures, the material was divided by the median, the upper half representing the 'mild' and the lower half the 'severe' cases.

The discriminant function analysis revealed that in 1964 the initially 'severe' group differed neither from the initially 'mild' group nor from the controls (Table VI). Thus the tendency to recover was not determined by the severity of the initial stage. It must be noted, however, that one patient had died from benzene poisoning in 1955, and his data are therefore not included in the analysis.

The differential count of the leucocytes yielded little of interest. Savilahti (1956) came to the same conclusion in his study of the acute stage. The only exception then was a marked absolute eosinophilia. The eosinophilic leucocytes in 1955 and 1964 are compared in Table VII, the figures indicating the number of cases. 
TABLE VI

Results of Discriminant Function Analysis Showing THAT NO DIFFERENCE COULD BE DEMONSTRATED BETWEEN THE INITIALly SEVERE AND MILD GROUPS at RE-eXAMINATION IN 1964

\begin{tabular}{lll} 
& $F$ & $P$ \\
\hline $\begin{array}{l}\text { Initially mild cases versus controls } \\
\text { Males }\end{array}$ & 1.60 & - \\
Females & 1.44 & - \\
$\begin{array}{l}\text { Initially severe cases versus controls } \\
\quad \text { Males }\end{array}$ & 2.18 & - \\
$\quad$ Females & 1.80 & - \\
Initially mild cases versus initially & & \\
$\quad$ severe cases & & \\
$\quad$ Males & 2.05 & - \\
$\quad$ Females & 0.66 & -
\end{tabular}

The eosinophilia has evidently decreased, thus suggesting that the high rate in 1955 was an effect due to benzene.

Statistical methods, dealing with groups, do not emphasize single cases. A few case reports will illustrate some special features. Case I demonstrates the development of leukaemia after a long period of good health, and case 2 shows a persisting insufficiency of the bone marrow. Case 3 is an example of a very severe intoxication from which recovery was almost complete.

Cases 4 to 16 represent severe intoxications (at least one of the following abnormalities in the acute stage: erythrocytes below 3 millions per $\mathrm{mm}^{3}$; leucocytes below 2,000 per $\mathrm{mm}^{3}$; thrombocytes below 100,000 per $\mathrm{mm}^{3}$ ). The results of the examinations in 1955 and 1964 are summarized in Table III. It appears that most patients have recovered; this agrees with the results of the multiple discriminant analysis of the entire group.
Case Reports

Case I A woman born in 1902 had been working in the shoe factory for six months. On one occasion the air of the workroom contained 470 p.p.m. of benzene. When first seen in April 1955, the patient complained of epistaxis, excessive bleeding from the vagina, and spontaneous haematomata.

On admission to hospital on April 4, 1955, her blood count showed: $\mathrm{Hb} 69 \%$, erythrocytes 3.1 millions $/ \mathrm{mm}^{3}$, colour index $\mathrm{I} \cdot \mathrm{I} \mathrm{I}$, leucocytes $1,300 / \mathrm{mm}^{3}$, no thrombocytes. The bone marrow showed a diminished erythropoiesis and plenty of toxic granules in the white series. No megakaryocytes were found. The patient received blood transfusions over a period of two months, at the end of which thrombocytes appeared in the smear. She was then sent home but was checked at frequent intervals. Her blood counts are shown in Figure 1 .

In October 1964, haemorrhages and spontaneous haematomata appeared. She was again sent to hospital. Her blood counts are shown in Table VIII.

The sternal marrow showed a lively normoblastic erythropoiesis with a few megaloblastic cells. No myelopoiesis was seen except for some eosinophilic cells. The smear was dominated by immature cells, the cytoplasm of which was either basophilically stained or absent. Plasma cells and plasma-cellular reticulum cells were abundant as well as mast cells and polykaryocytes. Neither megakaryocytes nor thrombocytes were detected.

The patient was bleeding continuously, and her condition worsened until she died on December 9, 1964. Unfortunately, no necropsy was carried out.

Case 2 A woman born in 1917 had been working in the same room as case I for seven years. When first seen, she was immediately admitted to hospital and given blood transfusions. Her blood counts are shown in Figure I. They have not reached normal levels, but the patient is subjectively well and is still working in the factory.

TABLE VII

\begin{tabular}{llllllll} 
& \multicolumn{2}{l}{ Eosinophils $(\%)$} & \multicolumn{2}{c}{ Total } \\
\cline { 2 - 7 } & $0-2$ & $2 \cdot 5-4$ & $4 \cdot 5-6$ & $6 \cdot 5-8$ & $8 \cdot 5-10$ & $10 \cdot 5-15 \cdot 5$ & \\
\hline Savilahti (1955) & 60 & 50 & 16 & 9 & 6 & 3 & 144 \\
Present study & 72 & 26 & 18 & 3 & 1 & - & 120
\end{tabular}

Present study

72

TABLE VIII

\begin{tabular}{|c|c|c|c|c|c|c|c|c|c|c|}
\hline \multirow[t]{2}{*}{ Date } & \multirow[t]{2}{*}{$H b(g . \%)$} & \multirow{2}{*}{$\begin{array}{l}\text { Erythro- } \\
\text { cytes } \\
\text { (millions) }\end{array}$} & \multirow[t]{2}{*}{ M.C.H. } & \multirow{2}{*}{$\begin{array}{l}\text { Leuco- } \\
\text { cytes }\end{array}$} & \multicolumn{5}{|c|}{ Differential Leucocyte Count (\%) } & \multirow{2}{*}{$\begin{array}{l}\text { Thrombo- } \\
\text { cytes }\end{array}$} \\
\hline & & & & & $\begin{array}{l}\text { Granulo- } \\
\text { cytes }\end{array}$ & $\begin{array}{l}\text { Eosino- } \\
\text { phils }\end{array}$ & $\begin{array}{l}\text { Baso- } \\
\text { phils }\end{array}$ & $\begin{array}{l}\text { Mono- } \\
\text { cytes }\end{array}$ & $\begin{array}{l}\text { Lympho- } \\
\text { cytes }\end{array}$ & \\
\hline 3.11 .64 & $6 \cdot 0$ & $2 \cdot 05$ & 29 & 2,000 & $7 \cdot 5$ & 一 & - & - & $92 \cdot 5^{\star}$ & $45, \infty 00$ \\
\hline 30.11 .64 & $8 \cdot 7$ & 2.92 & 30 & 5,400 & II.O & $\mathbf{I} \cdot \mathbf{O}$ & 一 & - & $88 \cdot 0^{\star}$ & 47,000 \\
\hline 7.12 .64 & $9 \cdot 4$ & $3 \cdot 25$ & 30 & 2,800 & $9 \cdot 0$ & $\mathbf{I} \cdot \mathbf{O}$ & - & - & $90 \cdot 0^{\star}$ & 59,000 \\
\hline 9.12 .64 & $6 \cdot 7$ & $2 \cdot 20$ & 30 & 5,800 & & & & & & 44,000 \\
\hline
\end{tabular}


TABLE IX

\begin{tabular}{|c|c|c|c|c|c|c|c|}
\hline \multirow[t]{2}{*}{ Patient } & \multirow[t]{2}{*}{ Sex } & \multicolumn{2}{|c|}{ Erythrocytes (millions) } & \multicolumn{2}{|c|}{ Leucocytes } & \multicolumn{2}{|c|}{ Thrombocytes } \\
\hline & & $I$ & II & $I$ & $I I$ & $I$ & $I I$ \\
\hline $\begin{array}{l}\text { M.J. } \\
\text { T.K. } \\
\text { E.R. } \\
\text { S.S. } \\
\text { V.S. }\end{array}$ & $\begin{array}{l}\mathbf{F} \\
\mathbf{F} \\
\mathbf{F} \\
\mathbf{F} \\
\mathbf{F}\end{array}$ & $\begin{array}{l}2.92 \\
3.80 \\
3.80 \\
3.60 \\
3.90\end{array}$ & $\begin{array}{l}4.00 \\
4.46 \\
4.70 \\
4.05 \\
4.80\end{array}$ & $\begin{array}{l}3,300 \\
3,600 \\
3,800 \\
3,200 \\
3,500\end{array}$ & $\begin{array}{l}6,200 \\
4,800 \\
9,100 \\
5,000 \\
5,800\end{array}$ & $\begin{array}{r}102,000 \\
52,000 \\
53,000 \\
93,000 \\
99,000\end{array}$ & $\begin{array}{l}430,000 \\
221,000 \\
206,000 \\
302,500 \\
432,000\end{array}$ \\
\hline $\begin{array}{l}\text { E.K. } \\
\text { I.S. } \\
\text { E.N. } \\
\text { I.R. }\end{array}$ & $\begin{array}{l}\mathbf{F} \\
\mathbf{F} \\
\mathbf{F} \\
\mathbf{F}\end{array}$ & $\begin{array}{l}4.00 \\
3.51 \\
3.30 \\
3.36\end{array}$ & $\begin{array}{l}4.10 \\
4.50 \\
4.75 \\
3.80\end{array}$ & $\begin{array}{l}4,400 \\
4,000 \\
2,600 \\
5,100\end{array}$ & $\begin{array}{l}5,600 \\
5,000 \\
6,200 \\
5,100\end{array}$ & $\begin{array}{l}96,000 \\
49,000 \\
90,000 \\
87,000\end{array}$ & $\begin{array}{l}246,000 \\
306,000 \\
225,000 \\
284,000\end{array}$ \\
\hline $\begin{array}{l}\text { A.S. } \\
\text { K.V. } \\
\text { P.K. } \\
\text { A.H. }\end{array}$ & $\begin{array}{l}\mathbf{F} \\
\mathbf{M} \\
\mathbf{M} \\
\mathbf{M}\end{array}$ & $\begin{array}{l}2.50 \\
4.32 \\
3.29 \\
3.95\end{array}$ & $\begin{array}{l}4 \cdot 30 \\
4 \cdot 22 \\
5 \cdot 10 \\
4 \cdot 15\end{array}$ & $\begin{array}{l}1,400 \\
2,600 \\
3,800 \\
2,600\end{array}$ & $\begin{array}{l}6,100 \\
4,000 \\
7,000 \\
6,400\end{array}$ & $\begin{array}{l}18,000 \\
99,000 \\
44,000 \\
91,000\end{array}$ & $\begin{array}{l}210,000 \\
261,000 \\
194,000 \\
257,000\end{array}$ \\
\hline & & 3.95 & I, May & II, Apri & & & \\
\hline
\end{tabular}

Case 3 The duration of exposure for this patient, a woman born in 1916, was six years. She had been working in the same atmosphere as cases $I$ and 2. During the initial stage blood transfusions were given.

The blood counts are given in Figure I.

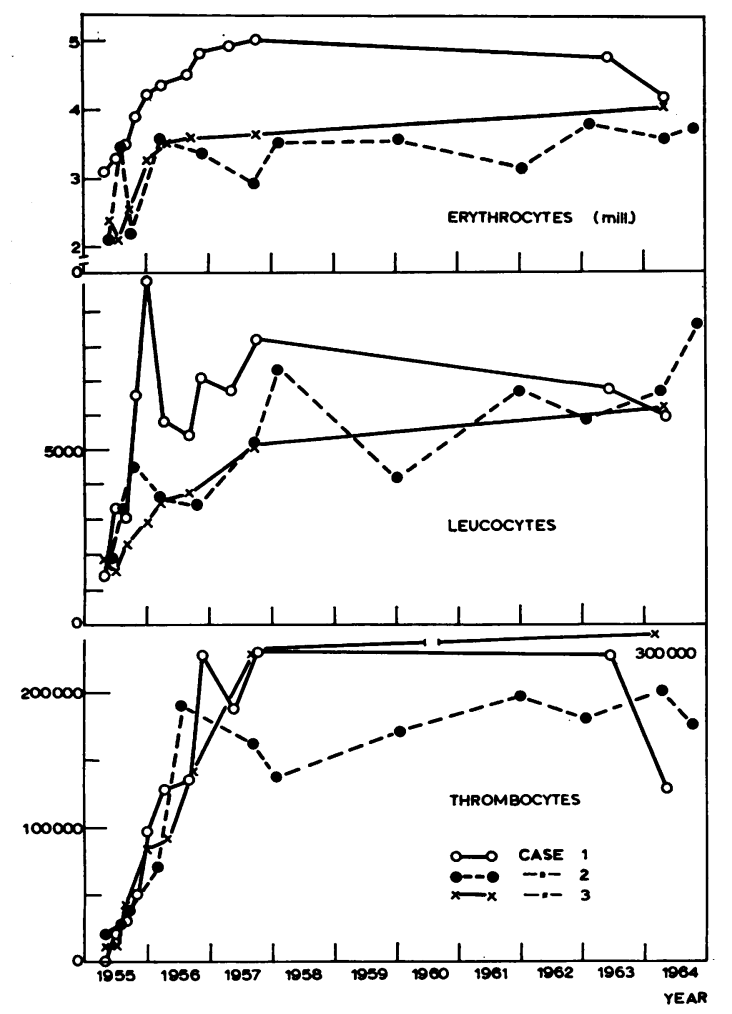

Fig. I. The erythrocyte, leucocyte, and thrombocyte counts of cases I to 3, 1955-64.

Cases 4 to 16 These cases are summarized in Table IX.

\section{Discussion}

In 1964, 58 persons-almost half the number who were re-examined-were in some respect below the generally accepted clinical range of normal haematological values. Even if it seems justifiable to blame some of the abnormalities on benzene, it is likely that other factors also influence the picture. For instance, the number of red cells, the element in which most of the pathological values occurred, is certainly influenced by iron supply. A comparison of the results with those obtained from a control group is therefore the only acceptable basis for conclusions. When the mean values of the single elements are compared, it appeared that only the thrombocytes of the whole group and the erythrocytes of the men were significantly lower than the corresponding values of the control series. According to this, the ability of the leucopoietic system to recover seems greater than that of the erythropoietic and especially the thrombopoietic system. This agrees with some earlier studies (Goldwater and Tewksbury, I94I; Mignolet, I950; Kauppila and Setälä, 1956; Coscia et al., 1963) but is contradictory to other reports in which leucopenia was the main persisting symptom, while the thrombocytes had achieved normal levels (Saita, 1955; Rejsek and Rejsková, 1955). For erythrocytes our results are in accordance with earlier studies, which as a rule indicate that persisting anaemia, even if frequent, is not the most common symptom.

So far, this concerns the group as a whole and does not reveal whether the persisting defects occurred in originally severe cases or not. The prognostic 
importance, if there is any, of each of the three haematological findings in question in the early stage is also interesting. This has been difficult to evaluate, due to the small size of the series and/or the short observation time.

An attempt to analyse our material failed to reveal any special significance of any single symptom. In 1964, no difference was found between those patients with low erythrocyte, leucocyte, or thrombocyte counts in 1955 on the one hand, and those with normal counts on the other. It is also interesting to note that when all the three counts were considered together, the multiple discriminant analysis did not reveal any difference in 1964 between the originally severe and originally mild groups. This may seem paradoxical at first sight. It must therefore be stressed that the statistical procedures involved only those who had survived the acute stage; deaths from benzene poisoning naturally constitute the most severe cases. In this series, only one patient died of progressive aplastic disease, and this may also influence the attempt to find a prognostic significance of a single symptom. Actually, almost all patients had a good prognosis.

It is evident that a statistical approach, even if it gives valuable data, does not tell everything. The case reports, especially those of cases I and 2, illustrate this statement. The low counts of case 2, persisting through the whole follow-up, are without doubt a result of benzene poisoning. There is thus at least one certain case of persisting damage to the bone marrow, even though the discriminant function analysis did not show any difference between the exposed females and the controls.

Case I had a very low thrombocyte count at the time of the group examination. This fact also escaped the multiple discriminant analysis because a few cases do not weigh heavily enough when large groups are analysed. The further course of the disease revealed that this patient was actually in a preleukaemic state at the time of examination. It is interesting to note that the onset of leukaemia was preceded by seven years of remission. Similar cases have been published before (Saita and Vigliani, 1962; DeGowin, 1963). The connexion between benzene poisoning and leukaemia can, of course, not be proved in this case, but the severity of the in- toxication in 1955 suggests an aetiological relationship.

The superficial haematological examination in I964 may be criticized. It is possible that a more thorough investigation would have revealed more defects. But when large numbers are studied, the demand for a thorough examination must be reduced. It is not possible to make as detailed observations on people actively engaged in their work as on patients in hospital. The number of examinations performed in the re-examination had therefore to be limited.

In spite of the two deaths and the slight haematological abnormalities recorded, the prognosis of these patients proved to be more favourable than might have been expected. This suggests that the prognosis of benzene poisoning cannot be evaluated solely in the light of reports of severe complications. The frequency of healed lesions must also be considered.

\section{REFERENCES}

Antila, V. (1962). Acta med. scand., 173, suppl. 393.

Coscia, G. C., Perrelli, G., and Meo, G. (1963). Folia med. (Napoli), 46, 791.

DeGowin, R. L. (1963). F. Amer. med. Ass., 185, 748.

Delore, P., and Borgomano (1928). F. Med. Lyon, 9, 227, cited by von Oettingen, W. F., 'Toxicity and Potential Dangers of Aliphatic and Aromatic Hydrocarbons'Publ. Health Bull. No. 255, Federal Security Agency, U.S. Publ. Health Service, Washington, 1940.

Fisher, R. A. (1938). Ann. Eugen., 8, 376.

Goldwater, L. J., and Tewksbury, M. P. (194I). F. industr. Hyg., 23, 217.

Helmer, K. J. (1944). Acta med. scand., 118, 354.

Kauppila, O., and Setälä, A. (1956). Ann. Med. intern. Fenn., 45, 49.

Mignolet, F. (1950). Arch. belges Méd. soc., 8, I17.

Rejsek, K., and Rejsková, M. (1955). Acta med. scand., 152, 71 .

Saita, G. (1955). Med. d. Lavoro, 46, 594.

and Vigliani, E. C. (1962). Ibid., 53, 581.

Savilahti, M. (1956). Arch. Gezverbepath. Gewerbehyg., 15, 147.

Vigliani, E. C., and Saita, G. (1964). New Engl. F. Med., $271,872$.

Wintrobe, M. M. (196r). Clinical Hematology, 5th ed., p. 554. Ed. H. Kimpton. Lea and Febiger, Philadelphia.

Zeyer, H. G. (196I). In Handbuch der gesamten Arbeitsmedizin, p. 429. Ed. E. W. Baader. Urban and Schwarzenberg, Berlin, Munich, Vienna. 